\title{
Aquatic Microplastic Research-A Critique and Suggestions for the Future
}

\author{
Judith S. Weis 1 \\ Department of Biological Sciences, Rutgers University, Newark, NJ 07102, USA; jweis@newark.rutgers.edu
}

Received: 1 May 2020; Accepted: 18 May 2020; Published: 21 May 2020

\begin{abstract}
While there are numerous papers on microplastics (mps) being published every week, there is a need for improvement for the field to mature. The papers reporting numbers found in water bodies cannot be compared because there are no standard methods for collection and analysis. It is clear that using nets for sampling misses most of the microfibers, which are the most abundant form when whole water samples are analyzed, and that microscopic identification has a very high error rate compared to chemical analytical equipment which can also identify the polymers. It is clear that most animals studied eat mps; we should learn what attracts the animals to the mps and what proportion pass right through and are defecated vs those that move into the tissues. It is considered that mps are a vector for transfer of toxic chemicals into the food chain. Let us investigate to what degree what proportion of contaminants are removed in the digestive system vs. staying bound tightly to the mps. Experimental studies should also use environmentally relevant doses and the shapes and sizes of mps that are most abundant in the environment.
\end{abstract}

Keywords: microfiber; analysis; consumption; trophic transfer; toxicity

\section{Introduction}

For decades, people have been concerned about the highly visible, ugly, and dangerous environmental pollution caused by plastics. We have seen pictures of marine animals that died from consuming plastic bags, getting entangled in six-pack rings, or with straws stuck in their nostril. However, in the past decade or so, there has been an enormous growth in research on a kind of plastic pollution that is less visible, namely microplastics (mps), which are small pieces of plastic, up to $5 \mathrm{~mm}$ in size. They can come from a variety of sources including fragmenting of larger pieces ("secondary mps") or being released directly as tiny particles ("primary mps"). Primary mps can come from a variety of sources including synthetic textiles, tires, personal care products, and "nurdles", (lentil size particles used in manufacturing larger plastic pieces). Mps come in various shapes (e.g., spheres, fibers, films, and fragments), sizes, colors, and chemical composition (polyethylene, polypropylene, polystyrene, etc.). Since they are so variable, it has been argued that they should not be considered a type of contaminant, but rather as a suite of contaminants [1]. Their environmental fate, uptake by organisms, and effects can be very different depending upon their size, shape, and chemical composition. As our knowledge grows, we have learned that they are everywhere, from the deepest ocean trenches [2] to remote mountain tops [3]. There is considerable concern about their effects since they attract toxic chemicals and appear to be everywhere including inside most organisms. Every week new articles are published in scientific journals, but not all of them are original or important. Many are duplicative, confusing, and perhaps spurious. We need to strengthen our research to better understand the problem.

\section{Collecting and Counting}

Many papers in the scientific literature report on the number of mp particles found in some water body, sometimes in the water, sometimes the sediments. Early reports of this nature were laying out the 
dimensions of the problem, but what is gained by paper after paper counting the numbers of particles in each water body? This information may be of interest to local residents and politicians, but is not of general interest, although it might be appropriate to publish in regional journals. Furthermore, these studies are often inaccurate and cannot be compared with one another because standardized methods for collection and analysis have not yet been established. It is urgent that this be done because worthwhile counting studies would compare, for example, the numbers in very similarwater bodies that have different human activities in their watersheds, or compare the same water body before and after some major change in waste management or policy regarding plastic pollution.

A number of things have become clear as a result of the plethora of sampling studies. First, collecting them by dragging plankton nets at the surface misses most of the microplastics, since different types of plastics have different densities and do not float at the surface [4]. In addition, thin microfibers and smaller particles, which are by far the most abundant type when whole water samples are analyzed, tend to pass through nets [5]. Most of the microfibers are derived from synthetic clothing via wastewater when laundered in washing machines, but also from fragmentation of ropes used in fishing gear [6]. Most of these are denser than water and tend to sink and accumulate in sediments, from which they are available to benthic organisms.

After collecting mps, some investigators count them under a microscope, which has a much higher error rate than sophisticated chemical equipment that can also provide information on the type of plastic $[7,8]$. Several authors have concluded that the visual identification by counting under a microscope can confuse plastic microfibers with, for example cotton, [9] and will also miss the smaller particles. (The lower size limit of mps is not defined, but since "nanoplastics" are defined as about one micron in size, particles larger than this would be considered microplastics.) Journal editors and reviewers for major journals should reduce the number of papers that they accept that merely report the presence of microplastics in a new place.

\section{Exposure}

Microplastics in the water and sediments can adhere to microbes, aquatic plants, and animals. In the environment, mps are colonized by microbes which form microfilms around the particles. These biofilms can alter weathering and vertical transport as well as sorption and release of contaminants by the mps [10] which may have ecological consequences. The nature of the microbial community of the microfilm is determined by spatial and seasonal factors as well as the nature of the microplastic (polymer, size, etc.). There is a possibility that microplastics can serve as vectors for pathogenic microorganisms [11].

The most highly studied type of exposure is by animals consuming them.

\section{Consumption by Animals}

Many studies document that some species of fish, plankton, or crab eat microplastics. This is of concern since, if mps are being eaten, they are an additional stress on marine organisms that are already under stress from many other environmental problems. Furthermore, if mps are getting into marine food webs, we might be consuming them in our seafood. New papers are continuously being published showing that another species eats mps. Some researchers collect animals from the field and examine their gut contents for mps, others perform laboratory studies in which the species of interest are found to eat the mps (generally microspheres) provided. It seems as if every animal studied eats them. Organisms that inhabit surface waters are likely to encounter microplastics with a density less than seawater such as polystyrene (PS), polypropylene (PP), and polyethylene (PE), while benthic organisms are more likely to encounter more dense plastic, including polyethylene terephthalate (PET) and polyvinyl chloride (PVC), so exposures are different [12]. It would be of interest to find a species that does not eat them or to find out why animals eat them-some animals appear to be attracted by the odor of the plastics or of the bacterial microfilm that forms around them [13], and others are attracted 
by the appearance of mps that resemble their natural food [14]. A fish that normally eats copepods that are blue in color is attracted to and preferentially consumes microparticles of similar size and color.

Although animals eat them, far fewer studies have examined how soon and how many are eliminated. Most of the experimental studies use microspheres, which are available commercially with uniform size, but are rare in the environment. Most mps may pass through the gut without causing any noticeable effects. The shape may be critical—spheres may pass through more easily than fragments with sharp edges which might damage the gut, or long fibers, which might clog up the gut.

Some have suggested that filter-feeding mollusks should be used as monitors for mps in the water $[15,16]$. Bivalves feed selectively, however, and in order to be used as a monitor, an animal should ingest most of the particles they encounter. Bivalves have been known for some time to be highly selective feeders [17]. Oysters, Crassostrea virginica, and blue mussels, Mytilus edulis, were offered different sized polystyrene microspheres and nylon microfibers. Both species rejected up to $98 \%$ of the spheres, especially the larger sizes, and rejected most of the microfibers. Particles to be rejected are bound in mucus, transported to the mantle, and expelled as pseudofeces. Of the mps that entered the digestive tract, differential egestion also occurred. Due to particle selection, the concentration of internal mps is far lower than that in the water, and the types of internal mps are very different from those in the environment. Thus, bivalves are very poor biomonitors for mp pollution [18].

Future studies should examine both ingestion and elimination rates and use shapes that are more prevalent in the environment, i.e., fibers, and concentrations that are not orders of magnitude greater than what is found in the environment. A study in the amphipod Hyalella azteca [19] reported slower egestion of fibers than spherical mps; however, complete egestion did occur for both shapes. Another recent study has found that while a shrimp defecates plastic spheres, they regurgitate the fibers. So, there is more than one way to eliminate plastic after eating it [20] and animals may deal differently with different shapes.

Plastics have also been found in the gills of the shore crab Carcinus maenas [21], so it is important to investigate respiration as another, and possibly very important, route of uptake. Since mps are also in the air and soil, there is a need for increasing the studies on respiratory intake in both land and soil-dwelling animals.

\section{Transfer out of the Gut}

If mps just pass through the gut, they are unlikely to do much damage. If they get stuck and clog up the digestive tract, there is the possibility of malnutrition and starvation. However, if they can penetrate though the gut lining and move elsewhere in the body, they are more likely to do damage. There are relatively few papers that demonstrate transfer out of the gut into other tissues. One such study in the water flea (Daphnia) fed them fluorescent microspheres that were later detected in other tissues [22]. However, a subsequent study found that it was the fluorescent dye itself, not the mps, that had moved to the other tissues [23]. A study of blue mussels [24] provided evidence of transfer of mps to the digestive gland causing an inflammatory response at the cellular level. There is a general tendency that smaller particles have a greater impact than larger plastic particles [25]. It also is reasonable that smaller particles are more likely to transfer through the gut wall into tissues. The number of particles reaching other organs does increase with decreasing particle size [26,27]. However, in some cases, larger mps can transfer from the intestinal tract: More plastic pieces were found in muscle than the gastrointestinal tract of a reef fish [28]. Furthermore, considerable numbers of relatively large plastic particles (124-438 $\mu \mathrm{m})$ were detected in the liver of three fish species [29].

\section{Trophic Transfer}

Transfer from a prey organism to its predator brings mps to species that may not themselves eat them directly, and to more species that we eat. There have been several studies of trophic transfer from prey species to predator. Batel et al. [30] established a simple freshwater food chain consisting of Artemia sp. nauplii and zebrafish (Danio rerio) and demonstrated the trophic transfer of mps and 
attached chemicals, but no noticeable effects were reported for virgin mps, without attached chemicals. However, some other trophic transfer studies fed the prey to the predator before allowing any time for elimination [31] and analyzed the predator for mps before it had time for elimination. We need realistic scenarios that give both predator and prey adequate time for elimination, use microfibers instead of microspheres, since microfibers are the most abundant in the environment, and provide the experimental subjects with "real" food.

Few studies have examined trophic transfer in the field [32,33]. When trophic transfer does occur, we do not know whether transferred particles are egested by the higher trophic level animal, or whether they bioaccumulate or biomagnify. To do this, the mps should accumulate in the tissues the way some chemical pollutants such as methylmercury do. Although there is some evidence that mps can transfer from the gut into organs, such as the liver [29] and brain [34], the extent to which this occurs and the particle sizes involved are poorly understood. Mesocosm studies would be very well suited for microplastic research since they provide a more realistic but controllable environment with organisms from different trophic levels in the same container.

\section{Effects}

The effects caused by any environmental contaminant are a very important issue. Papers have reported ill effects in various animals after eating microplastics. Most laboratory studies use microspheres, which are rare in the environment, and often use concentrations far greater than those found in the environment. Some studies do not provide "real" food to the animals-so the "effects" of the microplastics might really be due to malnutrition or a clogged digestive tract. Studies should include food in the diet, use microfibers, and allow time for elimination of mps.

In a study that compared the effects of microspheres, fragments and fibers on fish, researchers found that fibers accumulated more and were more damaging to the gut than either spheres or fragments [35]. As an example of thorough research, Horn et al. [36] studied mole crabs, which are filter-feeders in sandy beaches in the zone where waves break. The investigators used microfibers at concentrations that were found at the site from which the crabs were collected. They fed experimental and control gravid female crabs a commercial plankton diet and wore cotton clothing throughout the duration of the study, to avoid potential contamination from microfibers shed from their clothes. They noted the number of plastic fibers ingested by individual crabs and analyzed adult mortality and embryo development. They found that the microfibers increased adult mortality and affected embryonic development by increasing the number of embryonic stages. In contrast, many other studies, which may be done carefully, use the commercially available polystyrene spheres at unrealistically high doses. Different polymers, shapes, and sizes can have strikingly different effects.

Effects of mps have also been studied on aquatic plants. A review by Yokota et al. [37] found that microplastics can adhere to microalgae and alter algal photosynthesis, growth, gene expression, and colony size and morphology, possibly through transfer of adsorbed pollutants from microplastics. Marine microalgae Skeletonema costatum were exposed to micro-PVC (average diameter $1 \mu \mathrm{m}$ ) which inhibited growth with the maximum inhibition of $39.7 \%$ after $96 \mathrm{~h}$ exposure [38]. However, larger PVC particles $1 \mathrm{~mm}$ in diameter had no effects on growth. However, higher concentrations $(50 \mathrm{mg} / \mathrm{L})$ had negative effects on algal photosynthesis since chlorophyll content and photosynthetic efficiency decreased. Conversely, in freshwater macrophytes, Mateos-Cardenas et al. [39] found that polyethylene microplastics adhered to duckweed Lemna minor, but no effects on photosynthesis or growth were seen after seven-day exposure to 7 particles/mL. The amphipod Gammarus duebeni consumed the duckweed and trophic transfer occurred but no effects were seen in the amphipods' motility or mortality after $24-48 \mathrm{~h}$ exposure. Studying rooted macrophytes Myriophyllum spicatum and Elodea sp., Van Weert et al. [40] exposed plants to sediments amended with six concentrations of polystyrene $\mathrm{mp}$ (20-500 $\mu \mathrm{m}$, up to $10 \%$ dry weight) in the laboratory. Plants were tested for changes in root and shoot dry weight (DW), relative growth rate, shoot to root ratio, main shoot length, and side shoot length. 
Consistent dose-effect relationships were not observed except that main shoot length was reduced in M. spicatum with increasing mp concentration.

The numerous shapes, sizes, polymers, experimental conditions, exposure times, and concentrations used in the different studies make it very difficult to ascertain the important determining factors. Kögel et al. [41], in an extensive review article, discussed nine critical determining factors for microplastic effects: concentration, particle size, exposure time, particle condition, environmental condition, polymer type, species, developmental stage, and sex (Figure 1).

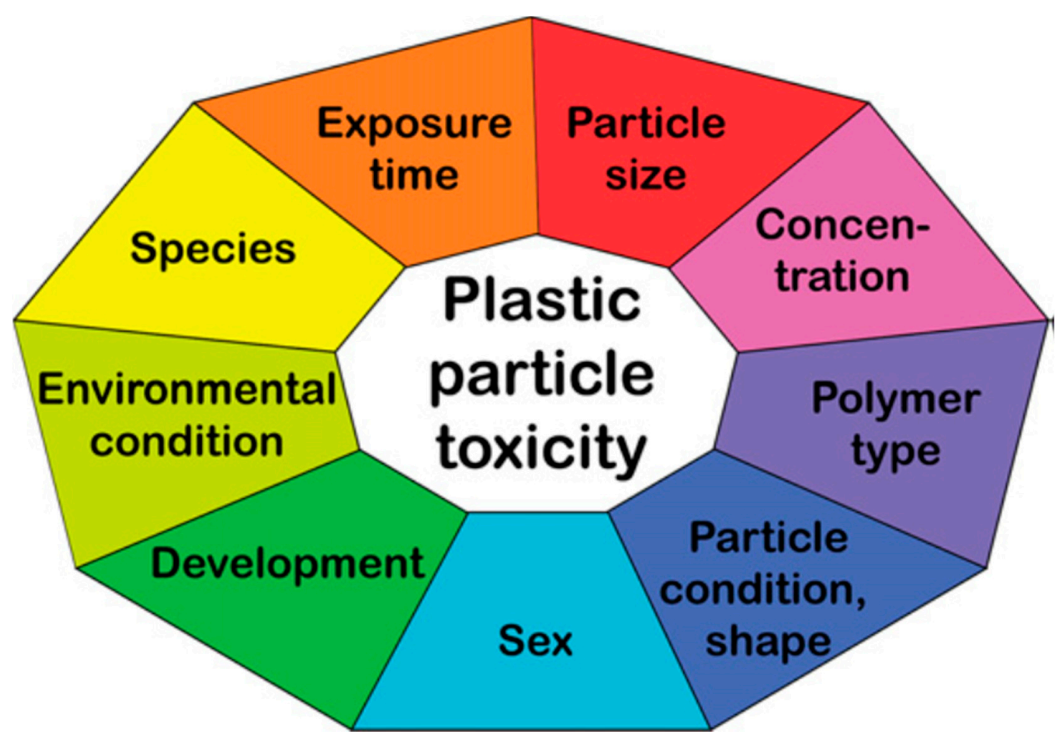

Figure 1. The nine main plastic particle toxicity determining factors, as found in the review. Kögel et al. (2020) [41] (open access).

Bucci et al. [42] assessed the environmental relevance of experimental studies by comparing the concentrations used in laboratory studies to the concentrations and sizes of microplastics found in the environment and found that fewer than $20 \%$ of the studies used concentrations found in nature, and that $80 \%$ of the particle sizes used in studies were below the size range found in environmental sampling. They recommended that future research be designed to better understand how different types, sizes, shapes, doses, and exposure durations affect biota and called for more environmentally relevant studies.

\section{Chemical Toxicity}

Plastics contain additive chemicals (such as phthalates and BPA) that can leach out and be toxic [43]. Furthermore, hydrophobic contaminants, such as PCBs (polychlorinated biphenyls) and pesticides, that adsorb to sediments and organic matter, have a great affinity for plastic surfaces [44]. Since these toxic chemicals readily bind to plastic, mps are considered "vectors" for transferring contaminants to animals and up the food chain [45]. The leaching of additives from plastic combined with the chemicals adsorbed to plastic renders mps a "cocktail" of toxic contaminants [46]. When particles containing adsorbed chemicals are ingested by an organism, pollutants can be released. While this has been shown in some studies, few demonstrate transfer to organisms with realistic scenarios such as providing the animals "real" food and time for elimination. Some studies found that the chemicals bind so tightly to the mps that the overall bioavailability from the environment is reduced [47] and that there is less transfer of toxic chemicals to organisms from plastics than from sediment, indicating that plastic is a less significant source $[48,49]$.

Zhu et al. [50] fed Japanese medaka (Oryzias latipes) diets amended with 500, 1000, or $2000 \mu \mathrm{g} / \mathrm{g}$ $10 \mu \mathrm{m}$ fluorescent spherical polystyrene mps for 10 weeks during maturation from juveniles to spawning adults. No changes in behavior, growth, or mortality occurred and mps were egested for 
3-4 days. Microscopic examination, histologic sections, and scanning electron microscopy showed no evidence of any translocation to other internal organs. Nevertheless, females showed dose-dependent decreases in egg number and histological analysis showed changes in kidney and spleen. Since no mps were found in tissues, effects were attributed to leaching of chemical additives such as DEHP (di(2-ethylhelyl)phthalate) from the particles.

In a study that did not involve ingestion, Le Bihanic et al. [51] exposed marine medaka Oryzias melastigma embryos and larvae to suspended mps spiked with benzo(a)pyrene (MP-BaP), perfluorooctanesulfonic acid (MP-PFOS), or benzophenone-3 (MP-BP3) for 12 days. The mps agglomerated on the surface of the egg chorion. While embryos exposed to virgin mps showed no toxic effects, those exposed to mps with PFOS had decreased embryonic survival and did not hatch. Larvae exposed to mps with BaP or mps with BP3 had reduced growth, developmental anomalies, and abnormal behavior. These investigators found that, compared to equivalent waterborne concentrations, $\mathrm{BaP}$ and PFOS spiked on mps appeared to be more embryotoxic than when chemicals were in seawater.

Since ingestion is the most commonly studied route of exposure, it is important to learn what proportion of additives and attached contaminants can be "pulled off" in the gut of different types of animals during the time that mps are passing through; this should vary with the chemical, the type of $\mathrm{mp}$, and the length, complexity, and chemistry of the digestive system (some invertebrates have alkaline stomachs rather than acidic stomachs like vertebrates). Such studies should primarily use microfibers, provide real food, and allow time for elimination. There is also a need for studying the availability of chemicals from microplastics in gills.

Environmental research alone will not solve the problems. Research in other fields is needed, especially textile science and washing machine technology. For example, filters on washing machines may be a way to reduce the release of microfibers. The Lint LUV-R filter captured an average of $87 \%$ of microfibers in the wash [52]. A bag to capture microplastics has been developed, but it captured only $18 \%$ of microfibers (https://seabinproject.com/seabin-project-tackling-microfibers-headon/). While all textiles shed, it is no surprise that fleeces shed the most [53]. Cotton and rayon also release microfibers, but they degrade in natural aquatic environments, while plastic microfibers do not [54]. However, improving washing machine technology will have only limited impacts, because it has been found that synthetic fabrics release equivalent amounts of microfibers (into the air) from being worn as from being laundered [55]. Going back to the source of the problem, it may be possible to re-engineer the manufacture of synthetic fabrics so that they will not shed (as many) fibers. For example, a protein has been isolated from squid that enables tears in fabrics to heal, and thus reduces fiber shedding [56]. Textile and materials scientists should collaborate with environmental scientists to help solve the problems $[57,58]$.

\section{Future Directions and Conclusions}

At this point, studies that count mps in shallow aquatic samples, use nets to collect them, and count them under a microscope should be limited to student projects, citizen science projects, and investigators with very limited resources, rather than mainstream science. More analysis of concentrations in mid-water and deep sediments in the ocean, including the abundance of different polymers, sizes, and shapes would be useful, viewing mps as a suite of contaminants. We need standardized methods so valid comparisons can be made. Additional studies documenting that other aquatic animals consume mps are also not cutting edge science. Future studies should examine ingestion and egestion rates, what attracts different species to consume mps, and investigate respiration as a route of exposure. Since microfibers are the most abundant form of mps in the environment, exposure and effects studies should focus mostly on them rather than convenient microspheres. More studies are needed to quantify and document routes and rates of transfer to other tissues from the gut, using environmentally representative types and concentrations of microplastics. We need realistic studies that quantify trophic transfer using environmentally relevant concentrations and types of microplastics, and which give both prey and predator real food and adequate time for egestion. 
Future studies of effects should use different polymers and shapes and provide real food, so that symptoms of starvation are not interpreted as effects of the plastic. Studies are needed on uptake and effects of microplastics acquired through respiration. Research is recommended to learn what fraction of adsorbed chemical contaminants of different types can be pulled off different types of mps during the time that they are traveling through digestive tracts of different organisms and the availability of environmental chemicals desorbed from microplastics in respiratory organs. Scientists in other fields are needed to develop ways of reducing the release of microplastics into the environment. Inexpensive attachments to washing machines that can trap them can be improved, and research into polymer chemistry and materials/textile science is needed to develop textiles that do not shed (as many) microfibers.

Funding: I had no funding for preparing this manuscript.

Acknowledgments: I thank Keith Cooper and Beth Ravit for inviting me to give a wrap-up talk at a conference on Microplastics in the Urban Environment, which stimulated my thinking about this topic.

Conflicts of Interest: The authors declare no conflict of interest.

\section{References}

1. Rochman, C.M.; Brookson, C.; Bikker, J.; Djuric, N.; Earn, A.; Bucci, K.; Athey, S.; Huntington, A.; McIlwraith, H.; Munno, K.; et al. Rethinking microplastics as a diverse contaminant suite. Environ. Toxicol. Chem. 2019, 38, 703-711. [CrossRef] [PubMed]

2. Courtene-Jones, W.; Quinn, B.; Gary, S.F.; Mogg, A.O.; Narayanaswamy, B.E. Microplastic pollution identified in deep-sea water and ingested by benthic invertebrates in the Rocksall Trough, North Atlantic Ocean. Environ. Poll. 2017, 231, 271-280. [CrossRef] [PubMed]

3. Allen, S.; Allen, D.; Phoenix, V.R.; Le Roux, G.; Jiménez, P.D.; Simonneau, A.; Binet, S.; Galop, D. Atmospheric transport and deposition of microplastics in a remote mountain catchment. Nat. Geosci. 2019, 12, 339-344. [CrossRef]

4. Taylor, M.L.; Gwinnett, C.; Robinson, L.F.; Woodall, L.C. Plastic microfibre ingestion by deep-sea organisms. Sci. Rep. 2016, 6, 33997. [CrossRef] [PubMed]

5. Green, D.S.; Kregting, L.; Boots, B.; Blockley, D.J.; Brickle, P.; Da Costa, M.; Crowley, Q. A comparison of sampling methods for seawater microplastics and a first report of the microplastic litter in coastal waters of Ascension and Falkland Islands. Mar. Pollut. Bull. 2018, 137, 695-701. [CrossRef]

6. Rocha-Santos, T.; Duarte, A. A critical overview of the analytical approaches to the occurrence, the fate and the behavior of microplastics in the environment. Trends Analyt. Chem. 2015, 65, 47-53. [CrossRef]

7. Browne, M.A.; Crump, P.; Niven, S.J.; Teuten, E.; Tonkin, A.; Galloway, T.; Thompson, R. Accumulation of Microplastic on Shorelines Worldwide: Sources and Sinks. Environ. Sci. Technol. 2011, 45, 9175-9179. [CrossRef]

8. Schymanski, D.; Goldbeck, C.; Humpf, H.U.; Fürst, P. Analysis of microplastics in water by micro-Raman spectroscopy: Release of plastic particles from different packaging into mineral water. Water Res. 2018, 129, 154-162. [CrossRef]

9. Song, Y.; Hong, S.; Jang, M.; Han, G.M.; Ran, M.; Lee, J.; Shim, W. A comparison of microscopic and spectroscopic identification methods for analysis of microplastics in environmental samples. Mar. Pollut. Bull. 2015, 93, 202-209. [CrossRef]

10. Rummel, C.; Jahnke, A.; Gorokhova, E.; Kuhnel, D.; Schmitt-Jansen, M. Impacts of biofilm formation on the fate and potential effects of microplastic in the aquatic environment. Environ. Sci. Technol. Lett. 2017, 7, 258-267. [CrossRef]

11. Oberbeckmann, S.; Loder, M.; Labrenz, M. Marine microplasic-associated biofilms-A review. Environ. Chem. 2015, 12, 551-562. [CrossRef]

12. Cole, M.; Lindeque, P.; Fileman, E.; Halsband, C.; Goodhead, R.; Moger, J.; Galloway, T. Microplastic ingestion by zooplankton. Environ. Sci. Technol. 2013, 47, 6646-6655. [CrossRef] [PubMed]

13. Savoca, M.S.; Tyson, C.W.; McGill, M.; Slager, C.J. Odours from marine plastic debris induce food search behaviours in a forage fish. Proc. R. Soc. B 2017, 284, 20171000. [CrossRef] [PubMed]

14. Ory, N.C.; Sobral, P.; Ferreira, J.L.; Thiel, M. Amberstripe scad Decapterus muroadsi (Carangidae) fish ingest blue microplastics resembling their copepod prey along the coast of Rapa Nui (Easter Island) in the South Pacific subtropical gyre. Sci. Total Environ. 2017, 586, 430-437. [CrossRef] [PubMed] 
15. Bonanno, G.; Orlando-Bonana, M. Perspectives on using marine species as bioindicators of plastic pollution. Mar. Pollut. Bull. 2018, 137, 209-221. [CrossRef] [PubMed]

16. Bråte, I.L.; Hurley, R.; Iversen, K.; Beyer, J.; Thomas, K.; Steindal, C.; Green, N.; Olsen, M.; Lusher, A. Mytilus species as sentinels for monitoring microplastic pollution in Norwegian coastal waters: A qualitative and quantitative study. Environ. Pollut. 2018, 243, 383-393.

17. Ward, J.E.; Shumway, S. Separating the grain from the chaff: Particle selection in suspension- and deposit-feeding bivalves. J. Exper. Mar. Biol. Ecol. 2004, 300, 83-130. [CrossRef]

18. Ward, J.E.; Zhao, S.; Holohan, B.; Mladinich, K.; Griffin, T.; Wozniak, J.; Shumway, S. Selective ingestion and egestion of plastic particles by the blue mussel (Mytilus edulis) and Eastern oyster (Crassostrea virginica): Implications for using bivalves as bioindicators of microplastic pollution. Environ. Sci. Technol. 2019, 53, 8776-8784. [CrossRef]

19. Au, S.Y.; Bruce, T.F.; Bridges, W.C.; Klaine, S.J. Responses of Hyalella azteca to acute and chronic microplastic exposures. Environ. Toxicol. Chem. 2015, 34, 2564-2572. [CrossRef]

20. Saborowski, R.; Paulischkis, E.; Gutow, L. How to get rid of ingested microplastic fibers? A straightforward approach of the Atlantic ditch shrimp Palaemon varians. Environ. Pollut. 2019, 254, 113068. [CrossRef]

21. Watts, A.J.; Urbina, M.A.; Goodhead, R.; Moger, J.; Lewis, C.; Galloway, T.S. Effect of microplastic on the gills of the shore crab Carcinus maenas. Environ. Sci. Technol. 2016, 50, 5364-5369. [CrossRef] [PubMed]

22. Rosenkranz, P.; Chaudhry, Q.; Stone, V.; Fernandes, T.F. A comparison of nanoparticle and fine particle uptake by Daphnia magna. Environ. Toxicol. Chem. 2009, 28, 2142-2149. [CrossRef] [PubMed]

23. Schür, C.; Rist, S.; Baun, A.; Mayer, P.; Hartmann, N.B.; Wagner, M. When fluorescence is not a particle: The tissue translocation of microplastics in Daphnia magna seems an artifact. Environ. Toxicol. Chem. 2019, 38, 1495-1503. [CrossRef] [PubMed]

24. Von Moos, N.; Burkhardt-Holm, P.; Koehler, A. Uptake and effects of microplastics on cells and tissue of the blue mussel Mytilus edulis L. after an experimental exposure. Environ. Sci. Technol. 2012, 46, 327-335. [CrossRef] [PubMed]

25. Chen, Q.; Gundlach, M.; Yang, S.; Jiang, J.; Velki, M.; Yin, D.; Hollert, H. Quantitative investigation of the mechanisms of microplastics and nanoplastics toward zebrafish larvae locomotor activity. Sci. Total Environ. 2017, 584, 1022-1031. [CrossRef] [PubMed]

26. Jeong, C.B.; Won, E.J.; Kang, H.M.; Lee, M.C.; Hwang, D.S.; Hwang, U.K.; Zhou, B.; Souissi, S.; Lee, S.J.; Lee, J.S. Microplastic size-dependent toxicity, oxidative stress induction, and p-JNK activation in the monogonont rotifer (Brachionus koreanus). Environ. Sci. Technol. 2016, 50, 8849-8857. [CrossRef]

27. Critchell, K.; Hoogenboom, M.O. Effects of microplastic exposure on the body condition and behaviour of planktivorous reef fish (Acanthochromis polyacanthus). PLoS ONE 2016, 13, e0193308. [CrossRef]

28. Karami, A.; Golieskardi, A.; Ho, Y.B.; Larat, V.; Salamatinia, B. Microplastics in eviscerated flesh and excised organs of dried fish. Sci. Rep. 2017, 7, 5473. [CrossRef]

29. Collard, F.; Gilbert, B.; Compere, P.; Eppe, G.; Das, K.; Jauniaux, T.; Parmentier, E. Microplastics in livers of European anchovies (Engraulis encrasiolus, L.). Environ. Pollut. 2017, 229, 1000-1005. [CrossRef]

30. Batel, A.; Linti, F.; Scherer, M.; Erdinger, L.; Braunbeck, T. The transfer of benzo [a]pyrene from microplastics to Artemia nauplii and further to zebrafish via a trophic food web experiment-CYP1A induction and visual tracking of persistent organic pollutants. Environ. Toxicol. Chem. 2016, 35, 1656-1666. [CrossRef]

31. Farrell, P.; Nelson, K. Trophic level transfer of microplastic: Mytilus edulis (L.) to Carcinus maenas (L.). Environ. Pollut. 2013, 177, 1-3. [CrossRef] [PubMed]

32. Furtado, R.; Menezes, D.; Santos, C.; Catry, P. White-faced storm-petrels Pelagodroma marina predated by gulls as biological monitors of plastic pollution in the pelagic subtropical Northeast Atlantic. Mar. Pollut. Bull. 2016, 112, 117-122. [CrossRef] [PubMed]

33. Hammer, S.; Nager, R.G.; Johnson, P.C.; Furness, R.W.; Provencher, J.F. Plastic debris in great skua (Stercorarius skua) pellets corresponds to seabird prey species. Mar. Pollut. Bull. 2016, 103, 206-210. [CrossRef] [PubMed]

34. Ding, J.; Zhang, S.; Razanajatova, R.; Zou, H.; Zhu, W. Accumulation, tissue distribution, and biochemical effects of polystyrene microplastics in the freshwater fish red tilapia (Oreochromis niloticus). Environ. Pollut. 2018, 238, 1-9. [CrossRef] [PubMed]

35. Qiao, R.; Deng, Y.; Zhang, S.; Borri-Wolosker, M.; Zhu, Q.; Ren, H.; Zhang, Y. Accumulation of different shapes of microplastics initiates intestinal injury and gut microbiota dysbiosis in the gut of zebrafish. Chemosphere 2019, 236. [CrossRef] [PubMed] 
36. Horn, D.; Granik, E.; Steele, C. Effects of environmentally relevant concentrations of microplastic fibers on Pacific mole crab (Emerita analoga) mortality and reproduction. Limnol. Oceanogr. Lett. 2020, 5, 74-83. [CrossRef]

37. Yokota, K.; Waterfield, H.; Hastings, C.; Davidson, E.; Kwietniewski, E.; Wells, B. Finding the missing piece of the aquatic plastic pollution puzzle: Interaction between primary producers and microplastics. Limnol. Oceanogr. Lett. 2017, 2, 91-104. [CrossRef]

38. Zhang, C.; Chen, X.; Wang, J.; Tan, L. Toxic effects of microplastic on marine microalgae Skeletonema costatum: Interactions between microplastic and algae. Environ. Pollut. 2017, 220, 1282-1288. [CrossRef]

39. Mateos-Cardenas, A.; Scott, D.; Seitmaganbetova, G.; van Pelt, F.; O’Halloran, J.; Jansen, M. Polyethylene microplastics adhere to Lemna minor (L.) yet have no effects on plant growth or feeding by Gammarus duibeni (Lillj.). Sci. Total Environ. 2019, 689, 413-421. [CrossRef]

40. Van Weert, S.; Redondo-Hasselerharm, P.; Diepens, N.; Koelmans, A. Effects of nanoplastics and microplastics on the growth of sediment-rooted macrophytes. Sci. Total Environ. 2019, 654, 1040-1047. [CrossRef]

41. Kögel, T.; Bjoroy, O.; Toto, B.; Bienfait, A.; Sanden, M. Micro- and nanoplastic toxicity on aquatic life: Determining factors. Sci. Total Environ. 2020, 709, 136050. [CrossRef] [PubMed]

42. Bucci, K.; Tulio, M.; Rochman, C. What is known and unknown about the effects of plastic pollution: A meta-analysis and systematic review. Ecol. Appl. 2020, 30, e02044. [CrossRef] [PubMed]

43. Seuront, L. Microplastic leachates impair behavioural vigilance and predator avoidance in a temperate intertidal gastropod. Biol. Lett. 2018, 14, 20180453. [CrossRef] [PubMed]

44. Hartmann, N.B.; Rist, S.; Bodin, J.; Jensen, L.H.S.; Schmidt, S.N.; Mayer, P.; Baun, A. Microplastics as vectors for environmental contaminants: Exploring sorption, desorption, and transfer to biota. Integr. Environ. Assess. Manag. 2017, 13, 488-493. [CrossRef] [PubMed]

45. Rochman, C.M.; Hoh, E.; Hentschel, B.T.; Kaye, S. Long-term field measurement of sorption of organic contaminants to five types of plastic pellets: Implications for plastic marine debris. Environ. Sci. Technol. 2013, 47, 1646-1654. [CrossRef] [PubMed]

46. Rochman, C.M. The complex mixture, fate and toxicity of chemicals associated with plastic debris in the marine environment. In Marine Anthropogenic Litter; Bergmann, M., Gutow, L., Klages, M., Eds.; Springer International Publishing: Berlin, Germnay, 2015; pp. 117-140. [CrossRef]

47. Rehse, S.; Kloas, W.; Zarfi, C. Microplastics reduce short-term effects of environmental contaminants. Part 1: Effects of bisphenol A on freshwater zooplankton are lower in the presence of polyamide particles. Int. J. Environ. Res. Public Health 2018, 15, 280. [CrossRef]

48. Beckingham, B.; Ghosh, U. Differential bioavailability of polychlorinated biphenyls associated with environmental particles: Microplastic in comparison to wood, coal and biochar. Environ. Pollut. 2017, 220, 150-158. [CrossRef]

49. Kleintech, J.; Seidensticker, S.; Marggrander, N.; Zarfi, C. Microplastics reduce short-term effects of environmental contaminants. Part II: Polyethylene particles decrease the effect of polycyclic aromatic hydrocarbons on microorganisms. Int. J. Environ. Res. Public Health 2018, 15, 287. [CrossRef]

50. Zhu, M.; Chermick, M.; Rittschof, D.; Hinton, D. Chronic dietary exposure to polystyrene microplastics in maturing Japanese medaka (Oryzias latipes). Aquat. Toxicol. 2020, 220, 105396. [CrossRef]

51. Le Bihanic, F.; Clérandeau, C.; Cormier, B.; Crebassa, J.-C.; Keiter, S.; Beiras, R.; Benedicte, M.M.; Begout, L.; Cousin, X.; Cachon, J. Organic contaminants sorbed to microplastics affect marine medaka fish early life stages development. Mar. Pollut. Bull. 2020, 154, 111059. [CrossRef]

52. McIlwraith, H.K.; Lin, J.; Erdle, L.M.; Mallos, N.; Diamond, M.L.; Rochman, C.M. Capturing microfibers-marketed technologies reduce microfiber emissions from washing machines. Mar. Pollut. Bull. 2019, 139, 40-45. [CrossRef] [PubMed]

53. Almroth, B.M.C.; Åström, L.; Roslund, S.; Petersson, H.; Johansson, M.; Persson, N.K. Quantifying shedding of synthetic fibers from textiles; a source of microplastics released into the environment. Environ. Sci. Pollut. Res. 2018, 25, 1191-1199. [CrossRef] [PubMed]

54. Zambrano, M.C.; Pawlak, J.J.; Daystar, J.; Ankeny, M.; Cheng, J.J.; Venditti, R.A. Microfibers generated from the laundering of cotton, nylon, and polyester based fabrics and their aquatic degradation. Mar. Pollut. Bull. 2019, 142, 394-407. [CrossRef] [PubMed]

55. De Falco, F.; Cocca, M.; Avella, M.; Thompson, R. Microfiber release to water, via laundering, and to air via everyday use: A comparison between polyester clothing with differing textile parameters. Environ. Sci. Technol. 2020, 54, 3288-3296. [CrossRef] 
56. Pena-Francesch, A.; Demirel, M. Squid-inspired tandem repeat proteins: Functional fibers and films. Front. Chem. 2019, 7, 69. [CrossRef]

57. Weis, J.S. Cooperative work is needed between textile scientists and environmental scientists to tackle the problems of pollution by microfibers. J. Textile Apparel Technol. Manag. 2018, 10, 1-3.

58. Weis, J.S. Improving microplastic research. AIMS Environ. Sci. 2019, 6, 326-340. [CrossRef]

(C) 2020 by the author. Licensee MDPI, Basel, Switzerland. This article is an open access article distributed under the terms and conditions of the Creative Commons Attribution (CC BY) license (http://creativecommons.org/licenses/by/4.0/). 